\title{
Census, reproductive biology, and germination of Astragalus gines-lopezii (Fabaceae), a narrow and endangered endemic species of SW Spain
}

\author{
Vanesa MARTÍNEZ-FERNÁNDEZ , Felipe MARTÍNEZ-GARCÍA , Félix PÉREZ-GARCÍA
}

\begin{abstract}
Astragalus gines-lopezii Talavera, Podlech, Devesa \& F.M.Vázquez (Fabaceae) is a threatened endemic species with a distribution restricted to a very small area in Badajoz Province (Extremadura Region, SW Spain) and only 2 populations are known. This species was catalogued in the "Endangered" category in the 2008 Red List and the 2010 Threatened Spanish Vascular Flora List. Despite its status as an endangered species, at present very little is known about the distribution, census, and reproductive biology of this species. In this study we have carried out an exhaustive census of $A$. gines-lopezii, and we have evaluated the production of flowers, fruits, and seeds and the existence or not of intra- and interpopulation variability in seed germination. Results have highlighted the high reproductive capacity of this species on the basis of a high production of flowers, fruits, and seeds. Mechanical scarification of seeds was effective for increasing germination. Thus, initial germination (22\%-60\%) was increased to $97 \%-99 \%$ when seeds were rubbed with sandpapers. A high intra- and interpopulation variability in seed germination was found in this species. A. gines-lopezii produces seeds with different degrees of physical dormancy, varying this grade among different individuals within a population.
\end{abstract}

\section{Introduction}

All Mediterranean-climate regions have a high number of rare and locally endemic taxa that survive as small populations, many of which are threatened by habitat transformation (Cowling et al., 1996). The genus Astragalus L. (Fabaceae) is one of the largest genera of vascular plants in the world, represented by approximately 2500 species (Akan and Civelek, 2001; Dinç et al., 2013; Karaman Erkul and Aytaç, 2013; Akan and Aytaç, 2014). The genus Astragalus is represented in the Iberian Peninsula by 41 species according to Podlech (1999), although $A$. devesae Talavera, A.González \& G.López was separated later from A. gines-lopezii Talavera, Podlech, Devesa \& F.M.Vázquez and the number has been raised to 42 (9 of them are endemic to Spain). Astragalus gines-lopezii is a threatened perennial herbaceous legume with a distribution restricted to a very small area in Badajoz Province (Extremadura Region, SW Spain). Astragalus gines-lopezii, A. nitidiflorus Jiménez Mun. \& Pau [an endemism of Cartagena (Murcia, SE Spain)], and A. devesae [an endemism of Ávila (Central Spain)] constitute the section Platyglottis Bunge in Spain. These 3 endemic species have a very restricted area and exiguous populations that initially were described as the same species, A. nitidiflorus (Pau, 1910; Vázquez et al. 1991). However, their detailed morphological study allowed the differentiation of the 3 species (Talavera, 1999; Talavera and Salgueiro, 1999).

Astragalus gines-lopezii was catalogued in the category "Endangered" (UICN, 2001) in the 2008 and 2010 Red Lists of Threatened Spanish Vascular Flora (Moreno, 2008; Martínez-García et al., 2010). The species was included in the "In danger of extinction" category in the Regional Catalogue of Threatened Species of Extremadura (Spain) (DOE, 2001). Despite its status as an endangered species, at present very little is known about the distribution and the census of this species. To know the distribution area of a taxon is the main step for evaluating its conservation status. According to the methodology of Iriondo (2011), groups of individuals that were separated from one another by a distance of $1 \mathrm{~km}$ were considered as belonging to different populations, assuming that gene flow was sporadic or negligible. The distribution of $A$. gines-lopezii was restricted to a very small area of the La Calera and María Andrés mountain ranges (Badajoz Province) (Calera and Andres populations, hereafter), although its exact distribution and census were undetermined (Ramos 
et al., 2010). Prior to this work, the Andres population was estimated to be fewer than 250 individuals, and a census of the Calera population did not exist (Ramos et al., 2010).

There are relatively few studies linking the germination ecology of endemic species from the Iberian Peninsula with the conservation of the species (Albert et al., 2002; Giménez-Benavides et al., 2005; Lorite et al., 2007; Copete et al., 2011; Fernández-Pascual et al., 2012). In most Fabaceae species, hard-seededness is the cause of the physical dormancy present in their seeds (Baskin and Baskin, 2001; Piotto and Di Noi, 2003; Zeng et al., 2005; Gresta et al., 2007; Can et al., 2009; Dittus and Muir, 2010; Kimura and Islam, 2012; Büyükkartal et al., 2013). Despite the relevance of the genus Astragalus, information on its germination characteristics is still partial and limited to a reduced number of Astragalus species (Acharya et al., 2006; Eisvand et al., 2006; Patane and Gresta, 2006; Kim et al., 2008; Martínez-Fernández, 2012). Prior to this work, Ramos et al. (2010) analyzed some germination characteristics of $A$. gines-lopezii seeds.

In 2009, 2010, and 2011, the potential area of occupancy of A. gines-lopezii was researched in order to identify new populations. The aims of this study were to (1) evaluate the conservation status of $A$. gines-lopezii by determining its chorology and census; (2) evaluate the production of flowers, fruits, and seeds; and (3) determine the existence or nonexistence of intra- and interpopulation variation in seed germinability.

\section{Materials and methods}

\subsection{Study species}

Astragalus gines-lopezii is an herbaceous perennial plant. It grows in a very small area within the mesomediterranean bioclimatic ranges of the La Calera and María Andrés mountain ranges (Badajoz Province) (Figure 1). The species grows on calcareous mountains at an altitude of between 420 and $680 \mathrm{~m}$ a.s.l. It produces inflorescence type raceme and legumes with a coriaceus pericarp. Flowering occurs throughout April and May, and the fruiting period occurs during May, June, and July. The timing of germination in the field is unknown. In the Calera population $\left(38^{\circ} 35^{\prime} \mathrm{N}\right.$, $\left.6^{\circ} 40^{\prime} \mathrm{W}\right), \quad A$. gines-lopezii plants are in vegetation communities with Quercus coccifera L., Olea europaea L., and Cistus albidus $\mathrm{L}$. In the Andres population $\left(38^{\circ} 31^{\prime} \mathrm{N}\right.$, $\left.6^{\circ} 39^{\prime} \mathrm{W}\right)$, A. gines-lopezii individuals appear in vegetation communities with Quercus ilex subsp. ballota (Desf.) Samp., Olea europaea subsp. sylvestris (Mill.) Lehr, Cistus albidus, Cistus ladanifer L., and Genista hirsuta Vahl.

\subsection{Chorology and census of the populations}

The 2 populations of $A$. gines-lopezii were $7 \mathrm{~km}$ from one another, and then the distance proposed by Iriondo (2011) was considered accurate. Data on the area of occupancy, altitude, habitat, and conservation status were collected for the 2 known populations of A. gines-lopezii (Calera and Andres populations; see Figure 1). About $26 \mathrm{~km}^{2}$ was visited to evaluate the number of individuals per population. The entire potential area where the species could be encountered was covered in 2009, 2010, and 2011. This area was searched twice a year by 3 persons in order to identify possible new populations. The census was done by dividing the area of each population in parcels of between 200 and $300 \mathrm{~m}^{2}$ in size and labeling plants with small markers that were counted (Iriondo, 2011). In each parcel, A. gines-lopezii plants were countered and classified into 1 of 2 age groups: reproductive plants and nonreproductive plants (Figure 2). The slope, the exposure, and the potential

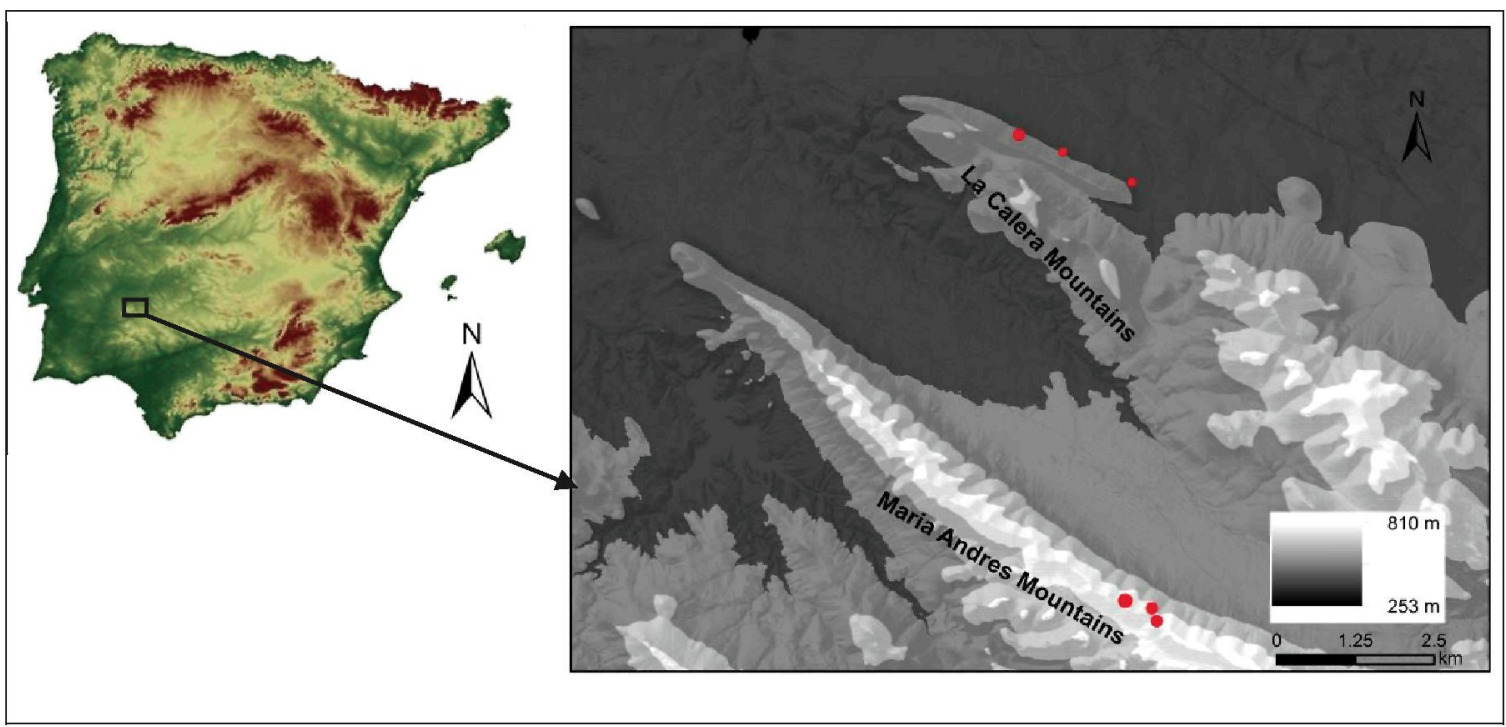

Figure 1. Location of the 2 known populations of Astragalus gines-lopezii (the approximate location of each subpopulation is marked with a red circle). 


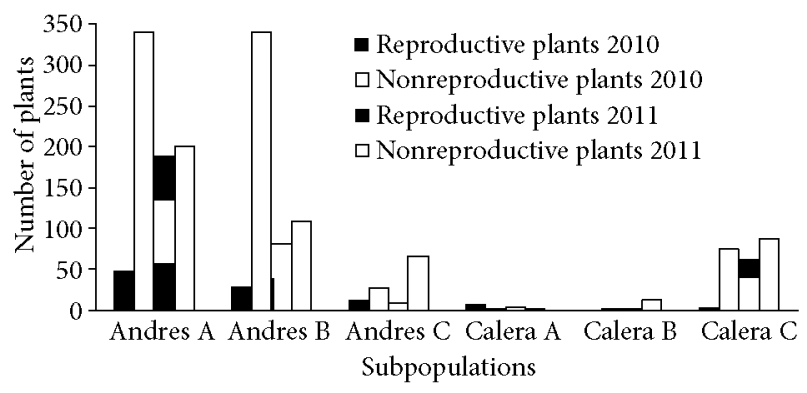

Figure 2. Number of reproductive plants and non reproductive plants recorded in the 2010 and 2011 censuses for the different subpopulations in the 2 known populations of Astragalus gineslopezii (Andres and Calera populations; see Figure 1).

threats for individuals were recorded for each population.

\subsection{Flower, fruit, and seed production}

Several randomly selected individuals from the Andres and Calera populations were marked in April 2009 to evaluate the production of flowers and fruits. The number of marked individuals was proportional to the population size ( 24 for Andres and 10 for Calera). In marked plants, the number of inflorescences per individual plant, flowers per inflorescence, and fruits per individual plant were evaluated. All ripe legumes from each marked individual plant were collected in June 2009. Then, in the laboratory, seeds were manually extracted from dried legumes and the number of seeds per fruit was recorded.

\subsection{General seed germination trials}

In all trials carried out, intact seeds (control) and scarified seeds (by abrasion of seed coat between 2 sheets of finegrained sandpaper) were tested for germination at the alternating temperatures of $25 / 15^{\circ} \mathrm{C}\left(25^{\circ} \mathrm{C}\right.$ for $16 \mathrm{~h}$ in light and $15^{\circ} \mathrm{C}$ for $8 \mathrm{~h}$ in dark). This temperature regime was chosen because many Mediterranean species present an optimal germination temperature ranging between $15^{\circ} \mathrm{C}$ and $25^{\circ} \mathrm{C}$ (Thanos et al., 1992; Baskin and Baskin, 2001). The light photoperiod was provided by cool white fluorescent tubes with an irradiance of $35 \mu \mathrm{mol} \mathrm{m}^{-2} \mathrm{~s}^{-1}$. Four replicates of 25 seeds each, or only 10 seeds (depending on the trial), were placed on top of 2 sheets of filter paper (previously moistened with $3.5 \mathrm{~mL}$ of distilled water) in glass petri dishes of $9 \mathrm{~cm}$ in diameter. Filter papers were rewetted regularly with distilled water as required. Dishes were checked every 2 days over a 35 -day test period and germinated seeds (radicle longer than $2 \mathrm{~mm}$ ) were counted and removed.

\subsection{Interpopulation variation in seed germination}

The aim of this trial was to detect seed germination differences between the 2 known populations of $A$. gines-lopezii. Seeds were collected in June 2009. In every population, collected seeds showed a similar degree of ripeness, as observed from their color and hardness. Seed samples of each population were manually cleaned, kept in paper bags, and then stored dry under laboratory conditions (approximately $23{ }^{\circ} \mathrm{C}$ under darkness) until they were used in the germination tests. Germination trials began in July 2009. Visibly deficient seeds were excluded from the experiments. In each trial, 4 replicates of 25 seeds each were tested for germination.

\subsection{Intrapopulation variation in seed germination}

Germination experiments were also carried out to detect germination differences among individual plants from the same population. Seeds collected from each marked individual plant (24 plants from the Andres population and 10 from the Calera population) were kept separately (without bulking). In this trial, only 20 seeds per individual plant (10 intact seeds and 10 scarified seeds) were tested for germination in order to avoid a substantial decrease in the number of seeds produced annually by both populations.

\subsection{Data analysis}

At the end of the germination period, the final cumulative germination percentage (mean value \pm standard error) and the mean germination time (MGT, mean value in days \pm standard error) were calculated. The latter was determined according to the following formula (Ellis and Roberts, 1981): $\mathrm{MGT}=\Sigma \mathrm{DN} / \Sigma \mathrm{N}$, where $\mathrm{D}$ is the number of days counted from the date of sowing and $\mathrm{N}$ is the number of seeds germinated on day D. In all germination trials, the number of empty seeds in each replicate was always excluded when calculating the final germination percentage. The values of final germination percentages were arcsine square-root transformed and then subjected to analysis of variance (ANOVA) (untransformed data appear in tables). The effects of population (2 levels) and scarification treatment (2 levels) on the final germination percentages were analyzed by a 2-way factorial ANOVA. Where ANOVA indicated a significant effect, a comparison of mean values was carried out through the least significant difference test (LSD) at 5\% level of significance using the computing package SPSS. The statistical analysis of MGT was also carried out with 2-way factorial ANOVA.

\section{Results}

\subsection{Chorology and census of the populations}

After 3 years of research, we finally can provide a detailed chorology of A. gines-lopezii (Figure 1). The total number of individuals recorded in 2009, 2010, and 2011 appear in Table 1; individuals are distributed in 2 populations over almost $0.16 \mathrm{~km}^{2}$. The populations were $7 \mathrm{~km}$ from one another. The Calera population consists of fewer than 170 individuals (2011 census) distributed in 3 subpopulations (Table 1). Sometimes, A. gines-lopezii appears within olive lands that are frequently tilled, constituting a risk for the population. Thus, in the Calera B subpopulation situated 
Table 1. Census data, altitude, latitude and longitude coordinates, and surface occupied related to the 2 known populations of Astragalus gines-lopezii (Calera and Andres populations; see Figure 1).

\begin{tabular}{llllllll}
\hline Subpopulation code & Altitude (m a.s.l.) & Latitude & Longitude & Surface $\left(\mathrm{km}^{2}\right)$ & 2009 census & 2010 census & 2011 census \\
\hline Calera A & 420 & $38^{\circ} 35^{\prime} \mathrm{N}$ & $6^{\circ} 40^{\prime} \mathrm{W}$ & 0.014 & 111 & 8 & 5 \\
Calera B & 440 & $38^{\circ} 35^{\prime} \mathrm{N}$ & $6^{\circ} 40^{\prime} \mathrm{W}$ & 0.014 & 59 & 1 & 15 \\
Calera C & 460 & $38^{\circ} 35^{\prime} \mathrm{N}$ & $6^{\circ} 39^{\prime} \mathrm{W}$ & 0.03 & 29 & 77 & 149 \\
Andres A & $650-680$ & $38^{\circ} 31^{\prime} \mathrm{N}$ & $6^{\circ} 39^{\prime} \mathrm{W}$ & 0.041 & 501 & 387 & 389 \\
Andres B & $650-680$ & $38^{\circ} 31^{\prime} \mathrm{N}$ & $6^{\circ} 39^{\prime} \mathrm{W}$ & 0.025 & 317 & 369 & 191 \\
Andres C & $660-680$ & $38^{\circ} 31^{\prime} \mathrm{N}$ & $6^{\circ} 39^{\prime} \mathrm{W}$ & 0.03 & 51 & 38 & 76 \\
Total & --- & --- & --- & 0.154 & 1068 & 880 & 825 \\
\hline
\end{tabular}

within an olive land, 94 individual plants were countered in April 2009, but this land was tilled in May 2009, and then only 59 individuals could be located in June 2009; in the 2009 census, that represented a loss of the $37.2 \%$ of this subpopulation. The Andres population contains the majority of the A. gines-lopezii individuals with almost 660 plants (2011 census) distributed in 3 subpopulations.

Both reproductive and nonreproductive plants were found together in all subpopulations studied. In most cases, the amount of nonreproductive plants was larger than reproductive plants (Figure 2 ). We also observed plants with old legumes that had been produced the previous summer. These legumes appear close to a mother plant and present a hard pericarp that prevents seed release.

\subsection{Flower, fruit, and seed production}

The proportion of reproductive plants for both populations was very variable and ranged from $11 \%$ to $80 \%$. Sexually mature individuals produced some inflorescences that usually had between 2 and 6 flowers. The average number of inflorescences and flowers per individual plant was 10.0 and 39.5, respectively. The number of inflorescences per sexually mature individual ranged from 1 to 29 (Table 2) and the number of flowers per plant ranged from 4 to 115 (Table 2). Mean values recorded for the Calera population were always higher than for the Andres population (Table 2). However, no significant differences in the number of inflorescences per individual $(P=0.153)$, the number of flowers per inflorescence $(\mathrm{P}=0.505)$, or total number of flowers per individual ( $\mathrm{P}=0.211$ ) were found between populations. The mean number of fruits per individual plant was 15.2 (ranging from 2 to 41) (Table 2). Mean number of fruits recorded for the Calera population was higher than for the Andres population (Table 2). However, no significant differences $(P=0.088)$ for this parameter

Table 2. Number (mean \pm SE, maximum, and minimum) of reproductive organs for Andres and Calera populations of Astragalus gineslopezii.

\begin{tabular}{|c|c|c|c|c|c|c|c|}
\hline \multirow{2}{*}{ Reproductive organs } & \multicolumn{3}{|c|}{ Andres $(\mathrm{n}=24)$} & \multicolumn{4}{|c|}{ Calera $(n=10)$} \\
\hline & Mean \pm SE & Max. & Min. & Mean \pm SE & Max. & Min. & P-value \\
\hline $\begin{array}{l}\text { Inflorescences } \\
\text { per individual plant }\end{array}$ & $8.2 \pm 1.39$ & 29 & 1 & $11.8 \pm 1.95$ & 20 & 2 & 0.153 \\
\hline $\begin{array}{l}\text { Flowers per } \\
\text { inflorescence }\end{array}$ & $3.8 \pm 0.22$ & 6 & 2 & $3.9 \pm 0.25$ & 5 & 2 & 0.505 \\
\hline $\begin{array}{l}\text { Flowers per } \\
\text { individual plant }\end{array}$ & $32.4 \pm 6.29$ & 115 & 4 & $46.6 \pm 8.74$ & 86 & 10 & 0.211 \\
\hline $\begin{array}{l}\text { Fruits per } \\
\text { individual plant }\end{array}$ & $11.8 \pm 2.07$ & 41 & 2 & $18.7 \pm 3.46$ & 38 & 2 & 0.088 \\
\hline $\begin{array}{l}\text { Success in flower-to- } \\
\text { fruit conversion }\end{array}$ & $40.9 \pm 5.35$ & 100 & 11.7 & $48.6 \pm 9.66$ & 100 & 8.0 & 0.455 \\
\hline Seeds per fruit & $11.5 \pm 0.75$ & 17 & 2 & $12.2 \pm 2.95$ & 17 & 6 & 0.351 \\
\hline
\end{tabular}

$\mathrm{n}$ : number of individuals sampled from each population.

P-value for each parameter signifies significance levels between populations. 
were found between populations. The proportion of flowers setting fruits was not high; it was $40.9 \%$ for the Andres population and $48.6 \%$ for the Calera population (Table 2). However, no significant $(\mathrm{P}=0.455)$ differences in this proportion were found between populations. The mean number of seeds per legume was 11.8 (ranging from 2 to 17) (Table 2). No significant $(P=0.351)$ differences in the number of seeds per fruit were found between populations.

Multiplying the total number of individuals recorded in 2010 (839) by the ratio of flowering individuals of this year $(0.16)$ by the mean number of legumes per individual plant (13.8) by the mean number of seeds per fruit (11.8), we get an output of more than 21,500 seeds at fruiting time in a year.

\subsection{Interpopulation variation in seed germination}

Significant differences $(\mathrm{P}<0.01)$ were found between populations for the final germination percentages reached by control seeds (22\% and 60\%) (Table 3). Mechanical scarification significantly $(\mathrm{P}<0.001)$ enhanced the final germination percentages in both populations $(97 \%$ and $99 \%$ ), although no significant differences $(\mathrm{P}>0.05)$ were found between populations. The interaction between population and treatment was significant $(P=0.001)$. Scarified seeds from both populations reached lower MGT values than control seeds, but only in the Calera population was this improvement in germination rate significant $(\mathrm{P}$ $<0.01)$. No significant differences $(\mathrm{P}>0.05)$ were found between both populations for the MGT values reached by control and scarified seeds. The interaction between population and treatment was not significant $(\mathrm{P}>0.05)$.

\subsection{Intrapopulation variation in seed germination}

In both populations, very high variability was found for the final germination percentages reached by control seeds $(0 \%$ to $80 \%$ and $0 \%$ to $70 \%$ for the Andres and Calera populations, respectively) and the germination was more uniform for scarified seeds (60\% to $100 \%$ and $70 \%$ to $100 \%$, respectively) (Table 4). Significant differences among individuals were only found for the Andres population and only for scarified seeds $(\mathrm{P}<0.05)$. For most individuals, MGT values reached by scarified seeds were lower than those of control seeds.

\section{Discussion}

The 2 known populations of $A$. gines-lopezii are located in Badajoz Province (SW Spain) and the distribution of the species was precisely detailed after 3 years of research (2009-2011).

Reproductive and nonreproductive plants were found together in all known subpopulations of A. gines-lopezii, instead of the distribution found by Ramos et al. (2010) for the same species. Results from the present study have highlighted the high reproductive capacity of $A$. gineslopeziion the basis of a high production of flowers and seeds, although this production is not so high if it is compared with data of $A$. nitidiflorus, one of the phylogenetically closest species to A. gines-lopezii in the genus (MartínezSánchez et al., 2011) (690 flowers per individual versus 39, respectively). However, the proportion of flowers setting ripe fruits is higher in $A$. gines-lopezii than in $A$. nitidiflorus ( $43 \%$ versus $21 \%$ ), although the mean number of seeds per ripe legume is similar (11.8 and 13 seeds, respectively).

The impermeable seed coat is the cause of the physical dormancy of many Fabaceae species (Baskin and Baskin, 2001; Piotto and di Noi, 2003; Baskin and Baskin, 2004; Eisvand et al., 2006; Finch-Savage and Leubner-Metzger, 2006; Patane and Gresta, 2006; Silveira and Fernandes, 2006; Gresta et al., 2007; Can et al., 2009; Pérez-García,

Table 3. Final germination percentage and mean germination time (MGT, days) of intact seeds (control) and mechanically scarified seeds from 2 Astragalus gines-lopezii populations. Results after 35 days of incubation at $25 / 15^{\circ} \mathrm{C}$ under a $16-\mathrm{h}$ light photoperiod. Mean values followed by different letters within columns are significantly different $(\mathrm{P}<0.05)$.

\begin{tabular}{|c|c|c|c|c|c|c|c|c|c|c|}
\hline \multirow{2}{*}{ Population } & \multicolumn{5}{|c|}{ Germination $(\% \pm \mathrm{SE})$} & \multicolumn{5}{|c|}{$\operatorname{MGT}($ days $\pm \mathrm{SE})$} \\
\hline & \multicolumn{2}{|c|}{ Control } & \multicolumn{2}{|c|}{ Scarified seeds } & $\mathrm{P}$ & \multicolumn{2}{|c|}{ Control } & \multicolumn{2}{|c|}{ Scarified seeds } & $\mathrm{P}$ \\
\hline Calera & \multicolumn{2}{|c|}{$60 \pm 3.16 b$} & \multicolumn{2}{|c|}{$97 \pm 1.66 \mathrm{a}$} & $* * *$ & \multicolumn{2}{|c|}{$7.95 \pm 0.52 \mathrm{a}$} & \multicolumn{2}{|c|}{$5.27 \pm 0.24 \mathrm{a}$} & $* *$ \\
\hline Andres & \multicolumn{2}{|c|}{$22 \pm 2.24 \mathrm{a}$} & \multicolumn{2}{|c|}{$99 \pm 0.87 \mathrm{a}$} & $* * *$ & \multicolumn{2}{|c|}{$13.77 \pm 3.09 \mathrm{a}$} & \multicolumn{2}{|c|}{$6.80 \pm 0.54 \mathrm{a}$} & ns \\
\hline ANOVA table & $\mathrm{df}$ & MS & $\mathrm{F}$ & $\mathrm{P}$ & & $\mathrm{df}$ & MS & $\mathrm{F}$ & $\mathrm{P}$ & \\
\hline Treatment (T) & 1 & 8362.19 & 249.98 & $<0.000$ & & 1 & 93.12 & 6.86 & 0.022 & \\
\hline Population (P) & 1 & 355.51 & 10.63 & 0.007 & & 1 & 54.02 & 3.98 & 0.069 & \\
\hline $\mathrm{T} \times \mathrm{P}$ & 1 & 732.78 & 21.91 & 0.001 & & 1 & 18.49 & 1.36 & 0.266 & \\
\hline Error & 12 & 33.45 & & & & 12 & 13.57 & & & \\
\hline
\end{tabular}

$P$ for each parameter and population signifies significance levels for control versus scarified seeds $\left({ }^{* *}: \mathrm{P}<0.001 ;{ }^{* *}: \mathrm{P}<0.01 ;\right.$ ns: not significant). 
Table 4. Final germination percentage and mean germination time (MGT, days) of intact seeds (control) and mechanically scarified seeds of Astragalus gines-lopezii belonging to 24 individuals from the Andres population and 10 from the Calera population. Results after 35 days of incubation at $25 / 15^{\circ} \mathrm{C}$ under a $16-\mathrm{h}$ light photoperiod.

\begin{tabular}{|c|c|c|c|c|}
\hline \multirow[t]{2}{*}{ Population } & \multicolumn{2}{|c|}{ Germination (\%) } & \multicolumn{2}{|l|}{ MGT (days) } \\
\hline & Control & Scarified seeds & Control & Scarified seeds \\
\hline \multirow[t]{24}{*}{ Andres } & 20 & 80 & 35.0 & 28.1 \\
\hline & 0 & 100 & --- & 5.6 \\
\hline & 0 & 100 & --- & 6.0 \\
\hline & 50 & 100 & 13.2 & 5.7 \\
\hline & 80 & 100 & 18.4 & 9.4 \\
\hline & 60 & 70 & 17.1 & 8.3 \\
\hline & 40 & 80 & 18.7 & 7.7 \\
\hline & 30 & 100 & 16.3 & 8.1 \\
\hline & 60 & 100 & 20.7 & 10.3 \\
\hline & 20 & 100 & 20.0 & 5.0 \\
\hline & 10 & 100 & 6.0 & 6.7 \\
\hline & 0 & 100 & --- & 6.0 \\
\hline & 60 & 90 & 5.0 & 6.0 \\
\hline & 40 & 100 & 15.7 & 6.0 \\
\hline & 0 & 100 & --- & 5.1 \\
\hline & 0 & 100 & --- & 5.7 \\
\hline & 20 & 100 & 7.5 & 4.5 \\
\hline & 10 & 100 & 6.0 & 5.4 \\
\hline & 20 & 90 & 6.0 & 5.7 \\
\hline & 20 & 100 & 20.0 & 5.4 \\
\hline & 20 & 100 & 4.5 & 5.1 \\
\hline & 10 & 100 & 13.0 & 3.6 \\
\hline & 60 & 60 & 26.3 & 6.5 \\
\hline & 20 & 100 & 30.5 & 4.8 \\
\hline Mean value $\pm \mathrm{SE}$ & $26.67 \pm 1.63$ & $94.58 \pm 2.20$ & $15.70 \pm 1.94$ & $7.11 \pm 0.95$ \\
\hline \multirow[t]{10}{*}{ Calera } & 10 & 100 & 6.0 & 6.0 \\
\hline & 30 & 100 & 2.7 & 6.0 \\
\hline & 20 & 80 & 19.6 & 7.2 \\
\hline & 70 & 100 & 7.9 & 8.2 \\
\hline & 70 & 80 & 7.9 & 6.9 \\
\hline & 20 & 100 & 14.0 & 6.0 \\
\hline & 30 & 90 & 8.3 & 7.3 \\
\hline & 30 & 70 & 10.7 & 6.4 \\
\hline & 20 & 90 & 9.5 & 4.0 \\
\hline & 0 & 100 & --- & 4.5 \\
\hline Mean value $\pm \mathrm{SE}$ & $30.00 \pm 6.93$ & $91.00 \pm 3.30$ & $9.62 \pm 1.53$ & $6.25 \pm 0.38$ \\
\hline
\end{tabular}

2009; Kimura and Islam, 2012; Büyükkartal et al., 2013). A high proportion of $A$. gines-lopezii seeds (40\% and 78\% for the Calera and Andres populations, respectively) did not germinate due to seed coat impermeability hindering the uptake of water; they will not germinate unless the seed coat is scarified. The results have shown that germination of control seeds was significantly lower that of mechanically scarified ones ( $60 \%$ and $22 \%$ versus $97 \%$ and $99 \%$ for Calera and Andres populations, respectively). Mechanical scarification is a technique to physically create 
scars on seed surface to increase water imbibition of the seeds (Rostami and Shasvar, 2009; Kimura and Islam, 2012). According to Baskin et al. (2006), a lack of water uptake was observed in ungerminated seeds of $A$. gineslopezii. Mechanical scarification of A. gines-lopezii hard seeds allows the rapid absorption of water by the seed and, as a consequence, the immediate germination. Thus, the germination percentage of scarified seeds is about $100 \%$.

Physical dormancy of the seeds means that not all the mature seeds produced by the same plant germinate at the same time. This reduces the chance that all the seeds will germinate in the same year. As a result, the risk of an extreme event damaging the seedlings decreases. Some of the seeds are then released and the seedlings develop under favorable environmental conditions. Physical dormancy of seeds is considered an adaptive role for plants that has been developed by numerous species and has been generalized in diverse families of plants over the course of their evolution (Cistaceae, Leguminosae, or Malvaceae) (Baskin and Baskin, 2001).

Given the high estimated seed production calculated for A. gines-lopezii, this increment does not correspond to a similar increase in the population. There was a decline of $22.7 \%$ in the number of total individuals between 2009 and 2011. The great difference between the estimation with mean values and the real data obtained by census supports the hypothesis of the existence of a soil seed bank or a delayed germination, although this hypothesis has not yet been confirmed. The observed decline in the number of plants could be related with a strategy of survival: for example, a bet-hedging strategy (Pake and Venable, 1996; Venable, 2007). However, long-term data on the demographic variations of $A$. gines-lopezii are necessary to test this hypothesis.

In many cases, seeds with an impermeable seed coat are longer-lived in natural conditions and accumulate in soil seed banks (Fenner, 1992; Baskin and Baskin, 2000; Van Assche et al., 2003). The relation between hard-seededness and seed bank dynamics has been reported in different annual legumes (Russi et al., 1992; Zeng et al., 2005). Specifically, Morris et al. (2002) checked the positive effect of light in the germination of buried seeds of Astragalus bibullatus Barneby \& Bridges. Under natural conditions, a number of factors (thermal oscillation between day and night, mechanical friction with soil particles, precipitation, etc.) would slowly and gradually alter the seed coat of hard seeds, promoting germination.

Our results are totally in agreement with the results obtained for other species of the genus Astragalus. For instance, for $A$. siliquosus Boiss., belonging to the IranoTuranian region, Eisvand et al. (2006) indicated that about $95 \%$ of seed dormancy is due to seed coat impermeability to water; the rest is related to physiological factors.
Mechanical scarification by sandpaper was the most appropriate treatment for enhancing the germination of A. siliquosus seeds, with no adverse effects on the embryo. However, the germination percentage reached by control seeds of $A$. siliquosus was lower (15\%) than in the case of A. gines-lopezii control seeds (60\% and $22 \%$ for the Calera and Andres populations, respectively).

Similarly, mechanical scarification with sand paper was the best treatment for breaking the physical dormancy of Astragalus hamosus L. seeds (Patane and Gresta, 2006). Germination percentage of nonscarified seeds of this species was less than $10 \%$, while all scarified seeds germinated. For Astragalus nitidiflorus Jiménez Mun. \& Pau, one of the nearest taxa to A. gines-lopezii with published results, scarification treatments also provided the best results (Carrión et al., 2007). The effectiveness of sandpaper scarification was also reported in Astragalus sinicus L. (Kim et al., 2008). However, the results obtained in this study for $A$. gines-lopezii disagreed with results obtained by Ramos et al. (2010) for the same species. In their study, 2 scarification treatments were applied (physical scarification and chemical scarification of the seeds by treatment with $96 \%$ sulfuric acid) under different light regimes (photoperiod and darkness). They found that nonscarified seeds presented the highest germination percentages $(80 \%)$. These authors also incubated the scarified seeds at $19^{\circ} \mathrm{C}$ in darkness, while control seeds were incubated at $21^{\circ} \mathrm{C}$ with a light/dark photoperiod of $12 \mathrm{~h} / 12 \mathrm{~h}$. Light regimes and temperature conditions could thus be determinant in the slow germination reached by scarified seeds against nonscarified seeds.

Our results indicated a high intra- and interpopulation variability in germination characteristics of $A$. gineslopezii. Final germination percentages of nonscarified seeds (control seeds) belonging to different individual plants ranged from $0 \%$ to $70 \%$ for the Calera population and from 0 to $80 \%$ for the Andrés population. Germination percentages of scarified seeds were more similar and uniform among individuals (from $80 \%$ to $100 \%$ ). These results suggest that individuals produce viable seeds with different grades of dormancy, maybe due to the different coat thicknesses and levels of impermeability. This variability would explain the varied germination percentage in control seeds of both populations. The production of seeds with different germination capacity is one of the most important survival strategies in plant species that live under variable and unpredictable environmental conditions (Kigel, 1995; Qaderi and Cavers, 2000; Baskin and Baskin, 2001; Cruz et al., 2003; Qaderi et al, 2005). The capacity for producing seeds with different degrees of physical dormancy is the mechanism by which plant species like A. gines-lopezii and many others (PérezGarcía, 1993, 2009; Kigel, 1995) are able to adapt to new 
environmental conditions, ensuring their survival because seeds can germinate later. It is probable that this variation, as it occurs in several others species (Pérez-García, 1993; Bewley and Black, 1994; Qaderi and Cavers, 2002), can be attributed to genetic differences among individual parent plants, even within a small geographic area. The above results highlight that the source (origin) of seed samples should always be taken into account when defining models of germination behavior, especially in wild species with a high degree of morphological and physiological variability.

In conclusion, A. gines-lopezii produces seeds with different degrees of dormancy, varying this grade among different individuals within a population. Therefore, seeds will overcome dormancy at different times and they will germinate progressively with time until they are viable in the soil. In general, mechanical scarification drastically improves the final germination percentages of these seeds. Many individuals of $A$. gines-lopezii did not produce dormant seeds, whereas others produced $100 \%$ physically

\section{References}

Acharya SN, Kastelic JP, Beauchemin KA, Messenger DF (2006). A review of research progress on cicer milkvetch (Astragalus cicer L.). Can J Plant Sci 86: 49-62.

Akan H, Aytaç Z (2014). The revision of the section Alopecuroidei of the genus Astragalus (Fabaceae) in Turkey. Turk J Bot 38: $37-59$.

Akan H, Civelek \$ (2001). Astragahus aytatchii (Fabaceae), a new species from Anatolia, Turkey. Ann Bot Fennici 38: 167-170.

Albert MJ, Iriondo JM, Pérez-García F (2002). Effects of temperature and pretreatments on seed germination of nine semiarid species from NE Spain. Isr J Plant Sci 50: 103-112.

Baskin CC, Baskin JM (2001). Seeds: Ecology, Biogeography, and Evolution of Dormancy and Germination. London, UK: Academic Press.

Baskin CC, Thompson K, Baskin JM (2006). Mistakes in germination ecology and how to avoid them. Seed Sci Res 16: $165-168$.

Baskin JM, Baskin CC (2000). Evolutionary considerations of claims for physical dormancy-break by microbial action and abrasion by soil particles. Seed Sci Res 10: 409-413.

Baskin JM, Baskin CC (2004). A classification system for seed dormancy. Seed Sci Res 14: 1-16.

Bewley JD, Black M (1994). Seeds: Physiology of Development and Germination. New York, NY, USA: Plenum Press.

Büyükkartal HN, Çölgeçen H, Pınar NM, Erdoğan N (2013). Seed coat ultrastructure of hard-seeded and soft-seeded varieties of Vicia sativa. Turk J Bot 37: 270-275.

Can E, Çeliktaş N, Hatipoğlı R, Avcı S (2009). Breaking seed dormancy of some annual Medicago and Trifolium species of different treatments. Turk J Field Crops 14: 72-78. dormant seeds. Therefore, individuals growing in close proximity produce seeds with very different dormancy levels. These data suggest a strategy to spread germination through time (but apparently not space) and to buffer drastic changes in population dynamics. Conservation strategies for this endangered species should evaluate factors that reduce fruit set and established plants and restrict seedling recruitment. The results described here could serve for determining conservation status and developing conservation strategies for A. gines-lopezii.

\section{Acknowledgments}

Thanks to Ángel Sánchez García, Elena Bermejo, and Marta Huertas for their help with this work. The Spanish Ministry of the Environment funded this research through the project Atlas y Libro Rojo de la Flora Vascular Amenazada de España, Fase IV (2009-2010). Thanks to 2 anonymous reviewers for their insightful comments and suggestions on the manuscript.

Carrión MA, Aznar L, Martínez JJ, Vicente MJ, Munuera M, Conesa E, Conesa F (2007). Luces y sombras en la conservación de Astragalus nitidiflorus. Conservación Vegetal 11: 35-37 (in Spanish).

Copete ME, Herranz JM, Ferrandis P, Baskin CC, Baskin JM (2011). Physiology, morphology and phenology of seed dormancy break and germination in the endemic Iberian species Narcissus hispanicus (Amaryllidaceae). Ann Bot 107: 1003-1016.

Cowling RM, Rundel PW, Lamont BB, Arroyo MK, Arianoutsou M (1996). Plant diversity in Mediterranean regions. Trends Ecol Evol 11:362-366.

Cruz A, Pérez B, Velasco A, Moreno JM (2003). Variability in seed germination at the intrapopulation and intraindividual levels of shrub Erica australis in response to fire-related cues. Plant Ecol 169: 93-103.

Dinç M, Aytaç Z, Dogŭ S (2013). A new species of Astragalus (Fabaceae) from Turkey. Turk J Bot 37: 841-846.

Dittus DA, Muir JP (2010). Breaking germination dormancy of texas native perennial herbaceous legumes. Native Plants 11:5-10.

DOE (2001). Decreto 37/2001, de 6 de Marzo, por el que se regula el Catálogo Regional de Especies Amenazadas de Extremadura. Diario Oficial de Extremadura (DOE), 13 de Marzo 2001, num. 30 (in Spanish).

Eisvand HR, Arefi HM, Tavakol R (2006). Effects of various treatments in breaking seed dormancy of Astragalus siliquosus. Seed Sci Technol 34: 747-752.

Ellis RH, Roberts EH (1981). The quantification of ageing and survival in orthodox seeds. Seed Sci Technol 9: 373-409.

Fenner M (1992). Seeds: The Ecology of Regeneration in Plant Communities. Wallingford, UK: CAB International. 
Fernández-Pascual E, Jiménez-Alfaro B, García-Torrico A, PérezGarcía F, Díaz TE (2012). Germination ecology of the perennial Centaurium somedanum, a specialist species of mountain springs. Seed Sci Res 22: 199-205.

Finch-Savage WE, Leubner-Metzger G (2006). Seed dormancy and the control of germination. New Phytol 171: 501-523.

Giménez-Benavides L, Escudero A, Pérez-García F (2005). Seed germination of high mountain Mediterranean species: altitudinal, interpopulation and interannual variability. Ecol Res 20: 433-444.

Gresta F, Avola G, Abate V (2007). Germination ecology of Scorpius subvillosus L. seeds: the role of temperature and storage time. Plant Ecol 190: 123-130.

Iriondo JM (2011). Atlas y Libro Rojo de la Flora Vascular Amenazada de España. Manual de Metodología del Trabajo Corológico y Demográfico. Madrid, Spain: Dirección General del Medio Natural y Política Forestal (Ministerio de Medio Ambiente, y Medio Rural y Marino), Sociedad Española de Biología de la Conservación de Plantas (in Spanish).

Karaman Erkul S, Aytaç Z (2013). Astragalus yukselii (Leguminosae), a new species from Turkey. Turk J Bot 37: 836-840.

Kigel J (1995). Seed germination in arid and semiarid regions. In: Kigel J, Galili G, editors. Seed Development and Germination. New York, NY, USA: Marcel Dekker, pp. 645-699.

Kim SY, Oh SH, Hwang WH, Kim SM, Choi KJ, Kang HW (2008). Physical dormancy in seeds of Chinese milk vetch (Astragalus sinicus L.) from Korea. Korean J Crop Sci 53: 421-426.

Kimura E, Islam MA (2012). Seed scarification methods and their use in forage legumes. Res J Seed Sci 5: 38-50.

Lorite J, Ruiz-Girela M, Castro J (2007). Patterns of seed germination in Mediterranean mountains: study on 37 endemic or rare species from Sierra Nevada, SE Spain. Candollea 62: 5-16.

Martínez García F, Martínez Fernández V, Bermejo E (2010). Astragalus gines-lopezii. In: Bañares Á, Blanca G, Güemes J, Moreno JC, Ortiz S, editors. Atlas y Libro Rojo de la Flora Vascular Amenazada de España. Adenda 2010. Madrid, Spain: Dirección general del Medio Natural y Política Forestal (Ministerio de Medio Ambiente, y Medio Rural y Marino)-Sociedad Española de Biología de la Conservación de Plantas, pp. 58-59 (in Spanish).

Martínez-Fernández V (2012). Evaluación del Estado de Conservación y Viabilidad Poblacional de Astragalus gineslopezii, un Endemismo Extremeño En Peligro (EN LR2008). Madrid, Spain: Escuela Técnica Superior de Ingenieros de Montes, Universidad Politécnica de Madrid (in Spanish).

Martínez-Sánchez JJ, Segura F, Aguado M, Franco JA, Vicente MJ (2011). Life history and demographic features of Astragalus nitidiflorus, a critically endangered species. Flora 206: 423432.

Moreno JC (2008). Lista Roja de la Flora Vascular Española Amenazada. Madrid, Spain: Ministerio de Medio Ambiente y Medio Rural y Marino (in Spanish).
Morris AB, Baucom RS, Cruzan MB (2002). Stratified analysis of the soil seed bank in the cedar glade endemic Astragalus bibullatus: evidence for historical changes in genetic structure. Am J Bot 89: 29-36.

Pake CE, Venable DL (1996). Seed banks in desert annuals: implications for persistence and coexistence in variable environments. Ecology 77: 1427-1435.

Patane C, Gresta F (2006). Germination of Astragalus hamosus and Medicago orbicularis as affected by seed-coat dormancy breaking techniques. J Arid Environ 67: 165-173.

Pau C (1910). Astragalus nitidiflorus Jiménez et Pau. Bol Soc Aragonesa Ci Nat 9: 130-131 (in Spanish).

Pérez-García F (1993). Effect of the origin of the cypsela on germination of Onopordum acanthium L. (Asteraceae). Seed Sci Technol 21: 187-195.

Pérez-García F (2009). Germination characteristics and intrapopulation variation in carob (Ceratonia siliqua L.) seeds. Span J Agric Res 7: 398-406.

Piotto B, Di Noi A (2003). Propagazione per Seme di Alberi e Arbusti della Flora Mediterranea. Rome, Italy: Agenzia Nazionale per la Protezione dell'Ambiente (ANPA) (in Italian).

Podlech D (1999). Astragalus. In: Talavera S, Aedo C, Castroviejo S, Romero Zarco C, Sáez L, Salgueiro FJ, Velayos M, editors. Flora Ibérica VII (I). Leguminosae. Madrid, Spain: Consejo Superior de Investigaciones Científicas, Real Jardín Botánico de Madrid, pp. 279-338.

Qaderi MM, Cavers PB (2000). Variation in germination response among local populations of Scotch thistle, Onopordum acanthium L. Seed Sci Technol 28: 881-886.

Qaderi MM, Cavers PB (2002). Interpopulation and interyear variation in germination in Scotch thistle, Onopordum acanthium L., grown in a common garden: genetics vs. environment. Plant Ecol 162: 1-8.

Qaderi MM, Presti A, Cavers PB (2005). Dry storage effects on germinability of Scotch thistle (Onopordum acanthium) cypselas. Acta Oecol 27: 67-74.

Ramos S, Rincón S, Vázquez FM (2010). Distribution and germination characteristics of Astragalus gines-lopezii: an endangered species. Ann Bot Fennici 47: 330-336.

Rostami AA, Shasvar A (2009). Effects of seed scarification on seed germination and early growth of olive seedlings. J Biol Sci 9: $825-828$.

Russi L, Cocks PS, Roberts EH (1992). Hard-seededness and seed bank dynamics of six pasture legumes. Seed Sci Res 2: 231-241.

Silveira FAO, Fernandes GW (2006). Effect of light, temperature and scarification on the germination of Mimosa foliosa (Leguminosae) seeds. Seed Sci Technol 34: 585-592.

Talavera S (1999). Sobre el tratamiento de la Tribu Astragaleae Bercht. \& J. Presl (Papilioideae, Leguminosae) en Flora Ibérica. Anales Jard Bot 57: 218-220 (in Spanish).

Talavera S, Salgueiro FJ (1999). Sobre el tratamiento de la familia Leguminosae en Flora Ibérica. Lagascalia 21: 155-222 (in Spanish). 
Thanos CA, Georghiou K, Kadis C, Pantazi C (1992). Cistaceae. A plant family with hard seeds. Isr J Bot 41: 251-263.

UICN (2001). Categorías y Criterios de la Lista Roja de la UICN: Versión 3.1. Gland, Switzerland and Cambridge, UK: Comisión de Supervivencia de Especies de la UICN (in Spanish).

Van Assche JA, Debucquoy KLA, Rommens WAF (2003). Seasonal cycles in the germination capacity of buried seeds of some Leguminosae (Fabaceae). New Phytol 158: 315-323.
Vázquez FM, Dominguez E, Devesa JA (1991). Nueva localidad de Astragalus nitidiflorus Jiménez y Pau en España. Acta Bot Malac 16: 486 (in Spanish).

Venable DL (2007). Bet hedging in a guild of desert annuals. Ecology 88: $1086-1090$.

Zeng LW, Cocks PS, Kailis SG (2005). Softening of impermeable seeds of six Mediterranean annual legumes on the soil surface and buried beneath the soil surface. Seed Sci Technol 33: 551-556. 